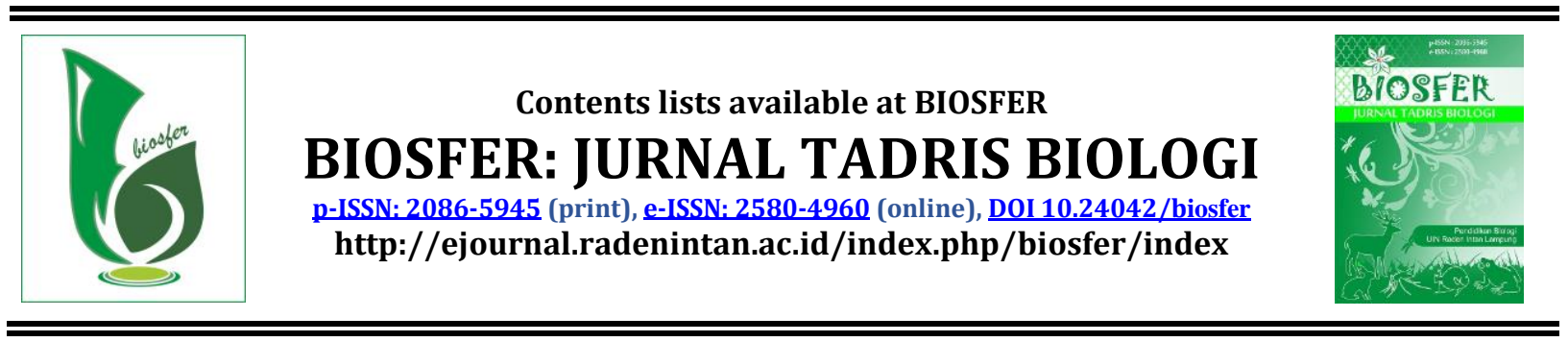

\title{
The Diversity Of Anura Order At Lake Gegas of Musi Rawas Regency, South Sumatera Province
}

\author{
Harmoko $^{1 *}$, Dian Samitra ${ }^{2}$, Sepriyaningsih ${ }^{3}$, Indra Yustian ${ }^{4}$, Arum Setiawan ${ }^{5}$ \\ 1, 2, 3 Biology Education, STKIP PGRI Lubuklinggau, Indonesia \\ 4, 5 Biology Education, Sriwijaya University, Indonesia
}

\begin{tabular}{|c|c|}
\hline ARTICLE INFO & ABSTRACT \\
\hline $\begin{array}{l}\text { Article History } \\
\text { Received : April 20th }, 2020 \\
\text { Accepted } \quad \text { : May } 7^{\text {th }}, 2020 \\
\text { Published }: \text { June } 29^{\text {th }}, 2020\end{array}$ & $\begin{array}{l}\text { The purpose of this study was to analyze the diversity of the Anura } \\
\text { order in Lake Gegas of Musi Rawas Regency, South Sumatra Province. } \\
\text { The research method employed was the cruising method. The cruise } \\
\text { was done in every part of Lake Gegas to record the Anura species. } \\
\text { Based on the results of the study, } 7 \text { species of Anura were found } \\
\text { consisting of } 5 \text { families and } 6 \text { genera. The most commonly found } \\
\text { species was the Fejervarya cancrivora. One species found in the IUCN's } \\
\text { Near Threatened (NT) category was the Limnonectes paramacrodon. } \\
\text { Based on the results of the study, it can be concluded that the Anura } \\
\text { order in Lake Gegas of Musi Rawas Regency, South Sumatra Province } \\
\text { was in the moderate diversity category. It was also found a species in } \\
\text { the near-threatened category called Limnonectes paramacrodon. }\end{array}$ \\
\hline $\begin{array}{l}\text { *Correspondence Address: } \\
\text { putroharmoko@gmail.com }\end{array}$ & $\begin{array}{l}\text { Keanekaragaman Ordo Anura di Danau Gegas Kabupaten Musi } \\
\text { Rawas Provinsi Sumatera Selatan } \\
\text { Abstrak: Tujuan dari penelitian ini adalah untuk menganalisis } \\
\text { keanekaragaman ordo Anura di Danau Gegas Kabupaten Musi Rawas } \\
\text { Provinsi Sumatera Selatan. Metode penelitian yang digunakan yaitu } \\
\text { dengan metode jelajah. Jelajah dilakukan di setiap bagian Danau } \\
\text { Gegas untuk mendata spesies ordo Anura. Berdasarkan hasil } \\
\text { penelitian, ditemukan } 7 \text { spesies ordo Anura yang terdiri dari } 5 \text { famili } \\
\text { dan } 6 \text { genus. Individu paling banyak ditemukan adalah Fejervarya } \\
\text { cancrivora. Ditemukan } 1 \text { spesies yang dalam IUCN kategori Near } \\
\text { Threatened (NT) atau "hampir terancam"yaitu Limnonectes } \\
\text { paramacrodon. Berdasarkan hasil penelitian dapat disimpulkan } \\
\text { bahwa: keanekaragaman ordo Anura di Danau Gegas Kabupaten Musi } \\
\text { Rawas Provinsi Sumatera Selatan dalam kategori keanekaragaman } \\
\text { sedang. Dan ditemukan spesies dalam kategori hampir terancam } \\
\text { yaitu Limnonectes paramacrodon. }\end{array}$ \\
\hline
\end{tabular}

\section{INTRODUCTION}

Indonesia is one of the countries with high biodiversity (Subowo, 2010;
Triyono, 2013). One of them is amphibians which is a natural wealth in Indonesia (Izza \& Kurniawan, 2014). Amphibians consist of 3 orders, namely 
Caudata, Gymnophiona, and Anura (Sarwenda dkk., 2016). Gymnophiona and Anura are two orders that are common in Indonesia. The species of Anura Order are recognized by Indonesian as frogs and toads (Rahayuningsih \& Abdullah, 2012; Doni Setiawan dkk., 2016; Wanda dkk., 2012).

Anura requires the availability of water in its life cycle for growth and breeding (Rahayuningsih \& Abdullah, 2012). Lake Gegas is a 3,864 hectares area in Musi, currently used as an irrigation area and water fish conservation. It is feared that the development of tourism in Lake Gegas will disturb the Anura Order's habitat.

The existence of these animals in nature is one indicator of environmental change in habitat (Martini et al, 2018; Wijaya, 2013). Anura is often treated as a food source and export commodities (Dwiastuti, 2010; Sason dkk., 2018; Wardhani, 2011). The role of Anura is important in maintaining the balance of the ecosystem and also in improving the economy which makes it important for us to find out more about the existence of this animal species (Qurniawan dkk., 2010). Kajian tentang Amfibi (Ordo Anura) The study of Amphibians (Anura Order) in Musi Rawas is very limited which had only been conducted in the Bukti Cogong II area (D. Setiawan dkk., 2016). Some studies on Anura around Musi Rawas had been conducted in Lubuklinggau (Samitra \& Rozi, 2020) and Empat Lawang (Izza \& Kurniawan, 2014).

Due to the lack of Anura order's data in the Musi Rawas Regency, the purpose of this study was to record and analyze the Anura Order in Lake Gegas of Musi Rawas Regency, South Sumatra Province.

\section{METHOD}

This study was descriptive qualitative research done by employing the exploratory method. This study was conducted in January-March 2020 at the Lake Gegas area of Musi Rawas Regency, South Sumatra Province. The identification was carried out in the Biology Laboratory of the Department of Mathematics and Natural Sciences of STKIP PGRI Lubuklinggau. The targets of this study were all species that belong to the Anura order around Lake Gegas of Musi Rawas Regency, South Sumatra Province.

The data was collected through the Visual Encounter Survey (VES) method. The research procedure employed was the cruising method. The data collection was done by exploring and observing the Lake Gegas in the morning and evening 10 times. The morning observations were done at 08.00-10.00 WIB (West Indonesian Time) and the evening observations were done at 19.00-20.00 WIB. The analyzed data covered species diversity, dominance, and uniformity.

\section{RESULTS AND DISCUSSION}

Based on the results of observations, the found Anura order consisted of 5 families, 6 genera, and 8 species within 78 individuals. More information can be seen in Table 1 . 
Biosfer: Jurnal Tadris Biologi, 11 (1) (2020) 11 - 16

Harmoko, Dian Samitra, Sepriyaningsih, Indra Yustian Arum Setiawan

Table 1. The Type of Anura Order at Lake Gegas of Musi Rawas, South Sumatra Province

\begin{tabular}{lllll}
\hline Family & Genus & Scientific name & IUCN & N \\
\hline Bufonidae & Duttaphrynus & Duttaphrynus melanostictus & LC-i & 7 \\
Microhylidae & Kaloula & Kaloula pulchra & LC-s & 1 \\
Rhacophoridae & Polypedates & Polypedates leucomystax & LC-s & 3 \\
Ranidae & Fajervarya & Fejervarya cancrivora & LC-i & 32 \\
& & Fejervarya limnocharis & LC-s & 12 \\
& Hylarana & hylarana erythraea & LC-s & 14 \\
& & Hylarana nicobariensis & LC-s & 6 \\
Dicroglossidae & Limnonectes & Limnonectes paramacrodon & NT-d & 3 \\
Total & & & & 78 \\
\hline
\end{tabular}

The results of diversity, dominance, and uniformity analysis of Anura order in Lake Gegas of Musi Rawas Regency, South Sumatra Province can be seen in Table 2.

Table 2. The Results of Anura Order Analysis at Lake Gegas of Musi Rawas Regency, South Sumatra Province.

\begin{tabular}{ccc}
\hline Index & Value & Category \\
\hline Diversity & 1.68 & Average \\
Uniformity & 0.80 & Stable \\
Dominance & 0 & Low \\
\hline
\end{tabular}

Based on the analysis of the species diversity index, the value of the Anura order was 1.68 within the moderate category. The uniformity index of the Anura order was 0.80 within the stable category and the dominance of the Anura order was 0 within the low category.

After calculating the percentage of the presence of each type, it was known that the most common type of Anura was Fejervarya cancrivora (41\%), Hylarana erythraea (18\%), and Fejervarya limnocharis (15\%). These three types were easily found because all three occupied broader niches and their higher defense mechanisms against predators (Qurniawan dkk., 2010). It also can be influenced by the ability of organisms to adapt to environmental conditions so that they can reproduce in that environment (Hull, 2008).

The least encountered type was Kaloula pulchra (1.28\%). This was this species occupied because the Kaloula pulchra occupied narrow niches, was highly dependent on water, and possessed low defense mechanisms against fewer predators (Qurniawan dkk., 2010).

Based on the analysis done by The International Union for Conservation of Nature Red List of Threatened Species (IUCN), most of the identified Anura belong to the least concerned category $(87.5 \%)$ and only one species belong to the vulnerable category $(12.5 \%)$. The following details are the data of the Anura order taken from IUCN at Gegas Lake which is divided into several categories. First, the Least Concern (LC) species with "Increasing" criteria consists of 2 species, namely Duttaphrynus melanostictus and Fejervarya cancrivora. Second, the Least Concern (LC) species with "Stable" criteria consists of 5 species, namely Kaloula pulchra, Polypedates leucomystax, Fejervarya limnocharis, Hylarana erythraea, and Hylarana nicobariensis. Lastly, the Near Threatened (NT) species with "Decreasing" criteria is Limnonectes paramacrodon. We need a way to help this species to develop properly because the Anura order is a wealth of natural resources that must be preserved so that the balanced structure of the ecosystem can be maintained properly (Maryetti dkk., 2016; Prabowo, 2001).

The information obtained is that there are no Anura orders at Lake Gegas that are classified as critical or 
endangered and there is only one type that is classified as near threatened.

The diversity index value of the Anura order at Lake Gegas was 1.68 within the moderate diversity category. The higher the $\mathrm{H}$ value, the higher the number of species, and the higher relative abundance (Asrianny dkk., 2018). This can happen because the geographical location of the group members is close together. The geographical location can determine the numbers and the types of its inhabitants.

The factors that also influence the level of diversity are the area and diversity of habitats (Triyono, 2013; Tuhumury \& Latupapua, 2014). Diversity is related to the number of types and the number of individuals of each type of community members (Hamzati \& Aunurohim, 2013; Maryetti dkk., 2016). The low diversity is due to land clearing to make rubber plantations around the Lake Gegas. The rubber plantations can disturb Anura's habitat.

The uniformity index value of Anura order at Lake Gegas was 0.80 within the stable uniformity category. The smaller the uniformity index, the smaller the population uniformity. This shows that the distribution of the number of individuals of each species is not the same so that there is a tendency for species to dominate and vice versa If the uniformity is greater (Erzad dkk., 2018; Laraswati dkk., 2020).

Furthermore, the dominance index value of the Anura order at Lake Gegas was 0 within the low dominance category. The dominance value ranges from $0-1$. If the dominance index is 0 , it can be seen that almost no individual dominates the community.

Anura order species are carnivorous when they are in their adult stage and herbivorous when they are in their tadpoles stage (Izza \& Kurniawan, 2014). Adult Anura species prey on worms, larvae, various types of animals from the
Arthropoda group, small shrimp, small fish, and shellfish. Amphibious tadpoles are preyed on by birds like Ardeidae, fish, aquatic insects, Odonata larvae, to tortoises. The main predators of adult Anura are birds and snakes.

Amphibians, especially the Anura order, are known to be sensitive to environmental conditions and can be used as bioindicators(Izza \& Kurniawan, 2014). The real impact of environmental change on Anura is the decline in population and species diversity (Fadli Wanda dkk., 2012).

\section{CONCLUSIONS AND SUGGESTIONS}

Based on the results of the study it can be concluded that the Anura order at Lake Gegas of Musi Rawas Regency, South Sumatra Province is in the moderate diversity category. The most threatened species found at the site was Limnonectes paramacrodon.

It is suggested for this research to be used as a reference to further develop this research.

\section{REFERENCES}

Asrianny, A., Saputra, H., \& Achmad, A. (2018). Identifikasi Keanekaragaman Dan Sebaran Jenis Burung Untuk Pengembangan Ekowisata Bird Watching Di Taman Nasional Bantimurung Bulusaraung. Perennial, 14(1), 17. https://doi.org/10.24259/perenni al.v14i1.4999

Dwiastuti, D. (2010). Kajian Tentang Kontribusi Cacing Tanah Dan Perannya Terhadap Lingkungan Kaitannya Dengan Kualitas Tanah. Biologi, Sains, Lingkungan, dan Pembelajarannya dalam Upaya Peningkatan Daya Saing Bangsa, 2(1), 448-452. 
Erzad, A. F., Hutabarat, S., \& Muskananfola, M. R. (2018). Distribution and Abundance of Fish Larvae in Coastal Waters of Bedono Village, Sayung, Demak Regency. Management of Aquatic Resources Journal, 6(4), 339-347.

Fadli Wanda, I., Novarino, W., \& Tjong, D. H. (2012). The Anuran species (Amphibia) at Harapan Rainforest, Jambi. Jurnal Biologi Universitas Andalas, 1(2), 99-107.

Hamzati, N. S., \& Aunurohim. (2013). Keanekaragaman Burung di Beberapa Tipe Habitat di Bentang Alam Mbeliling Bagian Barat, Flores. Jurnal Sains Dan Seni Pomits, 2(2), 121-126.

Izza, Q., \& Kurniawan, N. (2014). Eksplorasi Jenis-Jenis Amfibi di Kawasan OWA Cangar dan Air Terjun Watu Ondo, Gunung Welirang, TAHURA R.Soerjo. Biotropika: Journal of Tropical Biology, 2(2), 103-108.

Laraswati, Y., Soenardjo, N., \& Setyati, W. A. (2020). Komposisi dan Kelimpahan Gastropoda Pada Ekosistem Mangrove Di Desa Tireman, Kabupaten Rembang, Jawa Tengah. Journal of Marine Research, 9(1), 41-48.

Martini et al. (2018). Keefektifan Daun Kecubung Dalam Menghambat Penetasan dan Siklus Hidup Aedes aegypti. Jurnal Entomologi Indonesia, 15(1).

Maryetti, Sulistyadi, Y., Dananik, D., Nurhidayati, H., \& Setio, W. F. (2016). Pengembangan Berkelanjutan Kampung Budaya Setu Babakan Sebagai Daya Tarik
Wisata. Jurnal Destinasi Kepariwisataan Indonesia, 1, 2743.

Prabowo, R. (2001). Kadar Nitrit Pada Sumber Air Sumur DIkelurahan Meteseh, Kec. Tembalang, Kota Semarang. Cendikia Eksakta, 55(1), 55-61.

Qurniawan, T. F., Asti, H. A., \& Eprilurahman, R. (2010). Studi awal komunitas ordo anura di kawasan ekowisata Sawangan, Magelang, Jawa Tengah. Majalah Ilmiah Biologi BIOSFERA: A Scientific Journal, 27(3), 119-125.

Rahayuningsih, M., \& Abdullah, M. (2012). Persebaran Dan Keanekaragaman Herpetofauna Dalam Mendukung Konservasi Keanekaragaman Hayati Di Kampus Sekaran Universitas Negeri Semarang. Indonesian Journal of Conservation, $1(1)$.

Samitra, D., \& Rozi, Z. F. (2020). Short communication: The herpetofauna around human settlements in Lubuklinggau city, south Sumatra, Indonesia: Composition and diversity. Biodiversitas, 21(4), 1432-1437. https://doi.org/10.13057/biodiv/ d210422

Sarwenda, Subagio, \& Imran, A. (2016). Struktur Komunitas Amphibi di Taman Wisata Alam (TWA) Kerandangan dalam Upaya Penyusunan Modul Ekologi Hewan. Bioscientist: Jurnal Ilmiah Biologi, 4(1), 21-26.

Sason, H., Jusmaldi, \& Hendra, M. (2018). Keanekaragaman Avifauna di Objek Wisata Alam Air Terjun Berambai, Samarinda Kalimantan 
Timur. Jurnal Sylva LestariJurnal Sains dan Pendidikan Biologi, 2(1), 25-32.

Setiawan, D., Yustian, I., \& Prasetyo, C. (2016). Studi Pendahuluan: Inventarisasi Amfibi di Kawasan Hutan Lindung Bukit Cogong II. Jurnal Penelitian Sains, 18(2), 168289.

Setiawan, Doni, Yustian, I., \& Prasetyo, C. Y. (2016). Studi Pendahuluan: Inventarisasi Amfibi di Kawasan Hutan Lindung Bukit Cogong II. Jurnal Penelitian Sains, 18(2), 5558.

Subowo, G. (2010). Strategi efisiensi penggunaan bahan organik untuk kesuburan dan produktivitas tanah melalui pemberdayaan sumberdaya hayati tanah. Jurnal Sumberdaya Lahan, 4(1), 13-25.

Triyono, K. (2013). Keanekaragaman hayati dalam menunjang ketahanan pangan. INNOFARM: Jurnal Inovasi Pertanian, 11(1), 12-22.

Tuhumury, A., \& Latupapua, L. (2014). Keragaman Jenis Satwa Burung Berdasarkan Ketinggian Tempat pada Hutan Desa Rambatu Kabupaten Seram Bagian Barat Provinsi Maluku. Jurnal Hutan Tropis, 2(2), 94-106.

Wanda, I. F., Novarino, W., \& Tjong, D. H. (2012). Jenis-Jenis Anura (Amphibia) Di Hutan Harapan, Jambi. Jurnal Biologi Unand, 1(2).

Wardhani, M. K. (2011). Kawasan konservasi mangrove: Suatu potensi ekowisata. Jurnal Kelautan: Indonesian Journal of
Marine Science and Technology, $4(1), 60-76$.

Wijaya, E. W. (2013). Survei Awal Keanekaragaman Ordo Anura Di Desa Ketenger, Batu Raden, Jawa Tengah. Indonesian Journal of Conservation, 2(1). 